\title{
BELH FUKAHÂSININ YÖNETİCİLERE KARŞI DURUŞLARI: FEZÂİL-İ BELH BAĞLAMINDA
}

\author{
(1D Mehterhan FURKANİa
}

\begin{abstract}
Öz
Birçok mezhep imamı, yöneticilerin çeşitli baskısı ve tehditlerine maruz kalmış, ancak doğru bildikleri yoldan ayrılmamamış ve kendi ilke ya da prensiplerinden vazgeçmememişlerdir. Ebû Hanife hapse atılmış ve bu sebeple vefat etmiştir. Malik b. Enes'e ișkence uygulanmıș ve kolunu kaybetmiștir. Muhammed b. İdris eş-Şafiî̀nin çeşitli tehditlerle karşı karşıya kaldığı, muhtelif yerlere sürgün edildiği veya yer değiştirmek zorunda bırakıldığı bilinmektedir. Ahmet b. Hanbel de diğer imamlar gibi birçok sıkıntılarla karşılaşmıştır. Benzer şekilde Belh şehrinin fukahâsına baktığımızda da aynı davranışları sergilemeye devam ettiklerini, adil yöneticilerle iç içe olduklarını, yönetimde kadı ve müftü olarak çalışmalarına rağmen yeri geldiğinde yönetimle mesafe koyduklarını, hakkı ve doğruyu söyleme ya da savunma konusunda yöneticilerin baskı ve tehditlerine asla boyun eğmediklerini görmekteyiz.
\end{abstract}

Makalemizde "Fezâil-i Belh" adlı eserde yer alan rivayetleri esas alarak hicri 7. asrın başına kadar Belh şehrinde doğmuş, yaşamış veya bu şehre nispet edilmiş âlimlerin yöneticilere karşı örnek davranışlarından bazılarını ele alacağız. Konunun- istisnaları bulunsa da- genel itibarıyla fikıh âlimlerinin ictihâd yaparken kimsenin etkisi altında kalmadıklarına bir örnek teşkil etmesi açısından önemli olduğunu düşünüyoruz. Hanefî mezhebinin önemli bir merkezi ve ayağı konumunda bulunan, fikıh ve fukahâ şehri adıyla meşhur olan Belh, aynı zamanda idari açıdan da birçok hükümete başkentlik yapmıştır. Mezkur özelliklere haiz Belh șehrinin âlimlerini ve onların örnek davranıșlarını konu alan birtakım anekdotlara yer vereceğiz.

Anahtar kelimeler: İslam Hukuku, Fukahâ, Belh, Yöneticiler, Yöneticilere Karşı Duruşlar.

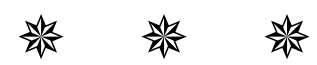

a Dr. Öğr. Üyesi, Aksaray Üniversitesi, mehterhan_4@windowslive.com 


\section{THE STANES OF BALKH JURISPRUDENCES AGAINST THE ADMINISTRATORS: IN THE CONTEXT OF FADAEL-E BALKH}

The imams of the four Sunni fiqh sects are the first examples for us in order not to give up their own principles because of the pressure and threats of the rulers. Abu Hanifa had imprisoned and finally had killed, Malik bin Anas had tortured and lost his arm, Mohammad bin Edris al-Shafiî had faced various threats, exiled from place to place or had to change places, Ahmad bin Hanbal also faced various problems; however, they are all upright until the end and make no concessions. When we look at the jurisprudences of the city of Balkh, we can see that, they had continued to exhibit the same behavior, they had worked in the administration as Kadi mufti with the fair rulers however, we also see that they had took a distance with the administration when necessary and that they never bow to the pressures and threats of the rulers regarding the right, truth and defense. In this article, we will consider a few examples of the behavior of scholars who were born, lived or attributed to the city of Balkh until the beginning of the 7th century hijri, against the rulers, based in the work titled on Fadael-e Balkh. We think that the subject is important in terms of being an example of the fact that fiqh scholars had not been under the influence of anyone while jurisprudence, although there are some exceptions.

We will give some example from the scholars of the city of Balkh, because this city is an important center of the fikh and Hanafi sect. It is also famous for the city of fiqh and it has also been the capital city of many governments.

[The Extended Abstract is at the end of the article.]

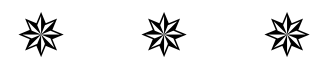

\section{Giriş: Fıkıh ve Fukahâ Açısından Belh Şehrinin Konumu}

7. asırda fethedilen Belh bölgesi de dini ilimler konusunda paya sahip olmuştur. İslam'ı kabul ettikten sonra kısa bir süre içerisinde ilim merkezi haline gelen Belh şehri tefsir, hadis, fikıh, tasavvuf, kelam vb. ilimlerde birçok âlim yetiştirdi. ${ }^{1}$ Camilerinde oluşturulan ilim halkalarının ${ }^{2}$ en yaygın ve

${ }^{1}$ Bu bölgelerde yetişen âlimlerle ilgili detaylı bilgi için bk. Muhammed Mahrûs Abdullatif el-Müderris, Meşâihu Belh mine'l-Hanefiyye ve mâ inferedû bihî mine'l-mesâili'l-fikhiyye (Bağdad: Darü'l-Arabiyye, 1979), 1: 49-112; Mehterhan Furkani, “Afganistan Topraklarında Yetişmiş Hanefi Fıkıh Alimleri”, İslam Hukuku Araştırmaları Dergisi, 28 (2016): 334-342.

2 Ebu İshak İbrahim b. Muhammed el-Farisî el-İstahrî, el-Mesâlik ve'l-memâlik (Beyrut: Dârü Sâdir, 2004), 265; Ya'kut b. Abdillah el-Hamevî, Mu'cemü'l-büldân, 2. Bs (Beyrut: Dârü Sâdir, 1995), 1: 480, 4: 201, 5: 397-397; İzzüddîn Alî b. Muhammed el-Cezerî İbnü'lEsîr, el-Lübâb fí tehzîbi'l-ensâb (Bağdâd: Mektebetü'l-Müsennâ, ts.), 1: 172, 2: 380, 3: 386. 
ağırlıkta olanı da fıkıh ilmine tahsis edilen halkalar olmuş ${ }^{3}$ ve bunun sonucunda da Belh șehri fikıh ilmiyle meşhur olup ${ }^{4}$ dâru'l-fekâhe, ${ }^{5}$ dâru'lfıkh ${ }^{6}$ ve hizânetü'l-fıkh ${ }^{7}$ gibi adlarla anılır olmuştur. Bazı dönemlerde sadece bu şehirde mescit ve cami sayısının 1848, medrese sayısının 400 ve müftü sayısının da 1200 'e ulaştığı rivayet edilmiştir. ${ }^{8}$ Bu özellikleri sebebiyle kendisine Kubbetü'l-İslam adı verilmiştir. ${ }^{9}$ Camilerde başlayan bu faaliyet, ilk olarak (875-99) Buhara'da Sâmânîler tarafından kurulmuş olduğu söylenen medrese sisteminin yaygınlaşmasıyla ortaya çımış, ${ }^{10}$ mescit ve camilerin yanında resmi ve gayrı resmi medreselerde günümüze kadar devam edegelmiştir. Belh şehrinde fikıh ilmi o kadar gelişmiş ki Belh âlimlerinin Hanefî mezhebi içinde ayrı bir ekol olduğunu dile getiren farklı görüşler bile ortaya çıkmıștır. ${ }^{11}$ Sözü edilen görüşlerin dayanak noktası, Ebu Hanife ve öğrencilerinin takip ettikleri yöntem doğrultusunda ictihâdda kimsenin etkisi altında kalmadan Kur'an'dan ve sünnetten özgür düşünce ile hüküm çıkartma metodudur. Hanefi fakihler bir taraftan ulü'l-emre itaate vurgu yaparken diğer taraftan da haksızlığa ve zorbalığa karşı çıkmada son derece hassas davranmışlardır. Belh fukahâsı da Hanefî mezhebinin bu temel prensibine sımsıkı sarılmış, bir taraftan adil yöneticilerin idaresinde kadılık, müftülük gibi önemli görevlerde bulunurken diğer taraftan da haksızlık yapan, zorba yöneticilere karşı hakkı söylemeyi ihmal etmemiştir. Makalemizde, Belh fukahâsının yöneticilere karşı duruşuyla ilgili rivayetlerden örneklere yer verilecektir.

\section{A. "Fezâil-I Belh" Adlı Eserin Tanıtımı}

Eser, hicrî 610 yılında Belh âlimlerinden Şeyhülislam Safiyyü'l-milleti ve'ddîn Ebû Bekir Abdullah b. Ömer b. Muhammed b. Davud, Va'iz-i Belhî

\footnotetext{
3 Muhammed Hasan Abdülkerim el-İmâdî, Horâsân fî asri'l-Gaznevî (b.y.: Müessesetü Hammâde li'l-Hademât ve'd-Dirasâti'l-Camiîyye ve Dârü'l-Kindî li'n-Neşri ve't-Tevdî', ts.), 256.

${ }^{4}$ Ebû Abdillah Muhammed b. Ahmed el-Makdisî, Ehsenü't-tekâsîm fî ma'rifeti'l-ekâlîm (Kahire: Mektebetü Medbûlî, 1411/1991), 294.

5 Ebu Bekir Abdullah b. Ömer b. Muhammed b. Dâvûd Vâiz-i Belhî, Fezâil-i Belh, thk. Abduhay Habibî, trc. Abdullah Muhammed b. Hüseyin Hüseynî el-Belhî (Tahran: Cengelek, 1388/2009), 29; Muvaffak b. Ahmed b. Muhammed el-Mekkî- Muhammed b. Muhammed b. Şihâb el-Bezzâzî el-Kerderî, Menâkibü'l-Imami'l-A'zam Ebî Hanîfe (Haydarâbâd: Matbaatü Dâireti'l-Mearifi'n-Nizamiyye, 1321/1903), 242.

${ }^{6}$ Müderris, Meșâihu Belh, 1: 35.

${ }^{7}$ Makdisî, Ehsenü't-tekâsîm, 34.

8 Vâiz-i Belhî, Fezâil-i Belh, 21.

${ }^{9}$ Müderris, Meşâihu Belh, 1: 32.

10 Îman bt. Suûd b. Hayşân el-Kureșî, el-Hayâtü'l-ilmiyye fí Belh hılâle'l-fetra 205-617/8201220 (Yüksek Lisans Tezi, Camiatü Ümmi'l-Kurâ, 1434/2013), 213.

11 Müderris, Meşâihu Belh, 2: 491-840.
} 
tarafından Arapça olarak telif edilmiştir. Eserin birinci bölümü Belh şehrinin faziletlerini, ikinci bölümü Belh şehrinin şemâilini ve üçüncü bölümü de sahabe döneminden müellifin dönemine kadar Belh şehrinde yaşamış ve o şehre mensup olan 70 âlimin biyografisini ihtiva etmektedir. Kitap, hicrî 676 yılında yine Belh âlimlerinden Abdullah Muhammed b. Muhammed b. Hüseyin Hüseynî Belhî tarafından Arapçadan Farsçaya çevrilmiştir.

Eserin Arapça metni günümüzde bulunmazken Farsça çevirisinin nüshaları da yakın zamanlarda ortaya çıkmıştır. Afgan tarihçisi Abdulhay Habibî, bir nüshasını Paris Milli Kütüphanesinde diğer iki nüshasını ise Rusya'yadaki Leningrad Bilimler Akademisi Kütüphanesinde bulup eseri 1969 yılında tahkik edip 1971 yılında yayınlamıştır.

\section{B. Fezâil-İ Belh Adlı Eserden Örnekler}

\section{Mütevekkil b. Humrân el-Kâdî (Ö. 141/758-9).}

Künyesi Ebû Abdilcebbar olan Mütevekkil b. Humrân tabiîndendir. Enes b. Malik'le görüşmüş, hicrî 142 yllında Belh'te şehit edilmiştir. Defnedildiği köy onun adıyla meşhur olmuştur. ${ }^{12}$ İbrahim b. Tahmân ${ }^{13}$ onu anlatırken "Yaşarken bir padişah gibi yaşadı, ahirete intikal ederken de şehit olarak gitti." ifadesini kullanmaktadır. Mütevekkil, şehit olduğunda 90 veya 104 yaşında idi. 52 yıl boyunca Belh'te kadılık yaptı. ${ }^{14}$

Rivayete göre Kuteybe onu ordu komutanı olarak atamış; Çaganiyan'a varınca bu bölgenin kadılığını, daha sonra da Belh kadılığını kendisine vermiştir. Ebû Müslim ${ }^{15}$ ayaklandığında Belh ehli ona karşı durmak için harekete geçtiler ve Serniğan'da savaştılar. Belhlilerin yenildiği bu savaşta Mütevekkil, Mukatil b. Hayyân, Mukatil b. Süleyman ve İbn Remmâh saklandılar. Ebû Davud ${ }^{16}$ 'un kendilerine eman mektubu göndermeleri neticesinde onun huzuruna geldiler. Ebû Davud Mütevekkil'e "Bize karşı savaştınız." deyince Mütevekkil: "Onların bizim üzerimizde hakları çoktu,

12 Vâiz-i Belhî, Fezâil-i Belh, 85.

13 İbrahim b. Tahmân b. Șu'be el-Herevî, Herat'ta doğmuș Nisapur ve Bağdat'ta ikamet etmiş sika ve meşhur muhaddislerden biridir. Hayatın sonunda Mekke'ye gitmiş ve hicri 168 veya 163 'te Mekke'de vefat etmiștir. bk. Ebü'l-Fadl Șihabuddîn Ahmed b. Ali İbn Hacer el-Askalâni, Tehzibu't-tehzîb (Beyrut: Dârü'l-Fikr, 1404/1984), 1: 112.

14 Vâiz-i Belhî, Fezâil-i Belh, 87. Hakkında detaylı bilgi için bk. Vâiz-i Belhî, Fezâil-i Belh, 85-89.

${ }^{15}$ Ebû Müslim Abdurrahman b. Müslim el-Mervî Horâsânî. Emevi devletini yıkıp Abbasî devletini Bağdat'ta sağlamlaştıran Horâsân'ın meşhur komutanıdır. Hicrî 100'de doğmuş, hicrî 137 yılında Medain'in Rume bölgesinde Abbâsî halifesi Mansur tarafından öldürülmüștür. bk. Hayreddîn b. Mahmûd Ziriklî, el-A'lâm (Beyrut: Dâru'l-İlm li'l-Melâîn, 2002), 3: 336-337.

${ }^{16}$ Ebû Müslim'in Belh'in fethi için görevlendirdiği komutanın adıdır. 
onları ödüyorduk. Şimdi hüküm sizin elinizde." diye cevap verdi. Ebû Davud, Mütevekkil'i serbest bırakıp onu Belh kadısı olarak atadı. O da istişare ettikten sonra Ebû Davud'un minberlerde isminin okunmaması, valinin atadığ 1 kişilerin şahitliğinin dinlenilmeyeceği, vali ve ordunun müslümanlardan aldıkları malları sahiplerine geri iade etmeleri şartıyla kadılığı kabul etti. Bunun üzerine anlaşma sağlandı.

Bir gün halife: "Bize mahsus olan konularda hüküm verme!" diye yazı

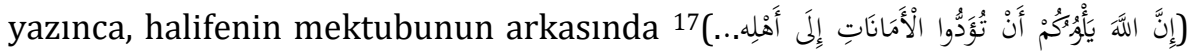
ayetini yazıp halifeye geri gönderdi. ${ }^{18}$

Başka bir gün iki kişi ona bir dava götürdüler. Onlardan biri de şehir emirinin ashabından idi. Mütevekkil, onun şahitliğini kabul etmeyip onun köyden çıkartılmasını emretti. Şahsın köyden çıkarıldığı haberi valiye ulaşınca kâsıt (haberci) gönderdi. Mütevekkil namazdayken yakalayıp Kunduz'a götürdüler. Orada 40 gün hapsettiler. Bir gün vali ona: "Minberlerde bana dua et ve şahitliğimi de kabul et." dedi. 0 da "hayır" deyince vali her iki elini, iki ayağını kestirdi ve başını bedeninden ayırttı. Vefatı esnasında kelime-yi tevhidi tekrarlıyordu.

Başka bir rivayete göre bir gün şehrin valisi olan Ebû Davud, Mütevekkil'in evine girdi. Mütevekkil o esnada tandırın başında oturuyordu. Ekmek yapan cariyesine: "Hamur sardığın deriyi at da vali üstünde otursun." dedi. 0 evde bir eşek, bir de içinde bir çocuk olan beşik bulunuyordu. Mütevekkil, Ebû Davud'a hitap ederek: "Senin böyle bütün hayırların toplandığı bir evin var mı?" diye sordu ve içinde yemek bulunan elindeki tabağı valiye uzatıp şöyle dedi: "Ey Ebû Davud! Bunu ye zira bu helal bir yemektir.” Ebû Davud, bu sözlerinden dolayı çok kızdı ve sinirli bir şekilde evden çıktı. Mütevekkil onu hiç dikkate almadı ve "Bu, Firavn'un Musa'ya olan kızgınlığı gibidir." dedi. Ebû Dâvûd, bu sözünden dolayı Mütevekkil'i öldürdü. Ebû Davud da bir gün damdan düştü, karnına bir mı girdi ve acı çekerek öldü. ${ }^{19}$

\section{2. Ömer b. Meymûn er-Remmâh (ö. 171/787)}

Künyesi Ebû Ali olan Ömer b. Meymûn er-Remmâh, döneminin zâhid ve sâlihlerinden olmakla beraber aynı zamanda çok yönlü bir âlimdi. Ebû Hanîfe'nin öğrencisi olan er-Remmâh, İmâm'ın kendisine saygı duyduğu ve

17 Nisa, 4/58: Ayetin tamamının meali şöyledir: Hiç şüphesiz Allah size, emanetleri ehline teslim etmenizi ve insanlar arasında hükmettiğiniz zaman adaletle hükmetmenizi emreder. Allah size ne güzel öğüt veriyor. Şüphesiz Allah işitir ve görür.

18 Vâiz-i Belhî, Fezâil-i Belh, 86-87.

${ }^{19}$ Vâiz-i Belhî, Fezâil-i Belh, 89-90. 
ilmi kişiliğini övdügü büyük bir âlimdir. Mütevekkil'den sonra Belh kadıllğını devraldı ve 20 seneyi aşkın bir sürede Belh kadılığında bulundu. Kadılık yaptığı sürede aynı zamanda her gün derslerle ve ilmî müzakerelerle meşgul oldu. Hem Nişabûr'da hem de Belh'te kadılık yapmış olduğu rivayet edilen Abdullah b. Ömer b. Remmâh'ın babasıdır. Hicrî 171 yılının Ramazan ayında Allah'ın rahmetine kavuştu. ${ }^{20}$ Ebû Mutî el-Belhî onun Kabil'den gelmesini, karanlık gecede yolculara dolunayın doğmasına benzemektedir. ${ }^{21}$

Rivayete göre Ömer b. Meymun köylerden birine gittiğinde, bir münker gördü. Ona tek başına engel olamayınca çevredekilerden yardım istedi. Onlar da yardım etmeyince nehy-i 'ani'l-münkerde bana yardım edilmeyen bir şehirde ikamet etmem." diye yemin edip Kâbe ziyaretine gitti ve Kabe'nin komşusu olmayı tercih edip orada kaldı. ${ }^{22}$

Muhammed b. Mutî babasının şöyle dediğini rivayet etmektedir:

"Remmâh hayatı boyunca ister halkın ilgi duyması için ister sultanın korkusundan olsun hiçbir sözü insanlardan saklamazdı. Yani hak yoluna devam ederdi. Doğruluk ve savaptan ayağını dışarı çıkarmazdı. ${ }^{23}$

\section{Ebû Mutî‘ el-Hakem b. Abdillah el-Kadî el-Belhî (Ö. 204/820)}

Ebû Mutî’ Hakem b. Abdillah b. Mesleme el-Belhî (ö.199/814)24 Ebû Hanîfe'nin öğrencilerinden biridir ve Ebû Hanîfe'ye nispet edilen el-Fıkhü'lekber ile el-Fıkhü'l-ebsat adlı eserlerin râvisidir. ${ }^{25}$ Ebû Yusuf, onun fikıhçılığı

\footnotetext{
20 bk. Vâiz-i Belhî, Fezâil-i Belh, 124-125; Yûsuf b. ez-Zekî Abdurrahmân Ebü'l-Haccâc elMizzî, Tehzîbü'l-Kemâl, thk. Beşşâr Avvâd Ma'rûf (Beyrut: Müessesetü'r-Risâle, 19831992), 21: 510-511; Ebû Muhammed Abdülkâdir b. Muhammed el-Kureșî, el-Cevâhirü'lmudıyye fi tabakâti'l-Hanefiyye (Dekken: Matba'atü Meclis-i Dâireti'l-Me'ârifi'nNizâmiyye, 1914), 1: 399.

${ }^{21}$ bk. Vâiz-i Belhî, Fezâil-i Belh, 125.

22 bk. Vâiz-i Belhî, Fezâil-i Belh, 124.

23 bk. Vâiz-i Belhî, Fezâil-i Belh, 127-128.

${ }^{24}$ Muhammed b. Sa'd b. Menî' İbn Sa'd, et-Tabakâtü'l-kebîr, thk. Ali Muhammed Ömer (Kahire: Mektebetü'l-Hancî, 2001), 7: 374; Muhammed b. Ali Hatîb el-Bağdâdî, Târîhu Bağdâd, thk. Beșșâr 'Avvâd Ma'rûf (Beyrut: Dârü'l-Garbi'l-İslâmî, 2001), 10: 194-195; Mehmet Şener, "Ebu Mutî’ el-Belhî”, Türkiye Diyanet Vakfı İslâm Ansiklopedisi (İstanbul: TDV Yayınları, 1994), 10: 194-195.

25 Ebû Abdillah Muhammed b. Ahmed ez-Zehebî, Mîzânü'l-i'tidâl fî nakdi'r-ricâl, thk. Muhammed Rıdvân Arkasûsî v.dğr. (Beyrut: Dâru'r-Risâleti'l-Âlemiyye, 2009), 1: 526; Carl Brockelmann, Tarihu'l-edebi'l-Arabî, trc. Abdulhalim en-Neccâr, 5. Bs (Mısır: Dârü'lMeârif, ts.), 3: 240; Takiyyuddîn b. Abdulkâdir el-Gazzî el-Mısrî et-Temîmî, et-Tabakâtu'sseniyye fi terâcimi'l-Hanefìyye, thk. Abdulfettah Muhammed el-Hulv (Kahire: Dârü'l-Kütüb, 1390/1970), 3: 178; Ebu'l-Feda Zeynuddîn Kasım b. Kutluboğa es-Sudûnî İbn Kutluboğa, Tâcü't-terâcim fí tabakâti'l-Hanefîyye (Dımașk: Dârü'l-Kalem, 1413/1992), 50; Mahmud b. Süleyman el-Kefevî, Ketâibü a'lâmi'l-ahyâr min fukahâ'i mezhebi'n-Nu'mâni'l-muhtâr, Rağib Paşa Kütüphanesi, nr. 1041, 81a.
} 
hakkında şöyle der: "ليس ماوراء الجسر أفقه من أبي مطيع البلخي" yani Dicle'nin ötesinde fikıhta Ebû Mutî”den daha bilgilisi yoktur. ${ }^{26}$ Abdullah b. Mübarek dindarlığ ve ilmî kişiliği sebebiyle ona saygı gösterirdi. ${ }^{27}$ Hanefi mezhebinde, özellikle de Horasan bölgesinde önemli bir konuma sahipti. ${ }^{28}$ Issâm b. Yûsuf, Ebû Hanife'nin vefatından sonra Ebû Yûsuf hariç, Ebû Mutî'den daha fakih birini görmediğini, günlerden birinde Ebû Mutî’in huzurunda Ebû Hanife'ye bir meseleyi sorduklarında, Ebû Hanife'nin Ebû Mutî’e işaret ederek “Sen fetva ver!" dediğini söylemektedir. Ebû Mutî', Ömer b. Meymûn er-Remmâh'tan sonra Belh kadılığına atandı ve 16 yıl boyunca Belh kadısı oldu. Hicrî 104 yılında 74 yaşında iken vefat etti. Belh şehrinde Nevbahar kapısında defnedildi. ${ }^{29}$

Ebû Mutî”e “İnsanlardan en yoksulu olan birine sadaka vereceğim, diye adak yapan kimse, adağının yerine getirilmesi için kime sadaka vermesi gerekiyor?" şeklinde soru sorulup fetva istenildiğinde "Adağının yerine getirilebilmesi için Belh emiri Ali b. İsâ'ya sadaka vermesi gerekiyor." diye cevap verdi. "Ne münasebetle?" diye sorulduğunda Ebû Mutî: "Çünkü Belh emiri halktan aldığı malı geri verirse elinde hiçbir şey kalmaz." diye cevap verdi. ${ }^{30}$

Rivayete göre halifeden bir mektup geldi, mektupta Yahya b. Bermek kastedilerek:

"yazılıydı. Ebû Mutî minbere çıktı, mektubu halka okudu. "Kim bu ayette Yahya b. Zekeriya'dan (a.s.) başka birinin kast edildiğini söylerse o kafirdir." dedi ve minberden inip evine gitti.

Bazı rivayetlere göre hatiplerin minberlerde Me'mun'u kast ederek "وآتيناه الحكم صبيا" söylemeleri emredilmiş̧ti. Ebû Mutî bunu duyunca, Belh'in meşhur ve büyük âlimleriyle beraber Belh emirinin yanına gitti. Belh emiri de onlara "Ben bu konuda bir şey söylemeye cesaret edemem ancak benim tarafımdan bir endişeniz olmasın, bu hükmü siz benden daha iyi bilirsiniz." dedi.

Bunun üzerine Ebû Mutî minbere çıkıp şöyle dedi: "Hilafet makamından gelen mektupta وآتيناه الحكم صبيا ayetiyle Me'mun’un kast edildiği

26 bk. Vâiz-i Belhî, Fezâil-i Belh, 24 .

27 Kefevî, Ketâib, 81a.

${ }^{28}$ Halil b. Abdullah b. İbrahim b. Halil Ebu Ya'la el-Halilî, el-İrşad fi ma'rifeti ulemâi'l-hadis, thk. Muhammed İdris Ömer İdris (Riyad: Mektebetu'r-Rüşd, 1409/1989), 3: 925.

29 bk. Vâiz-i Belhî, Fezâil-i Belh, 146-147; Kureşî, Cevâhirü'l-mudiyye, 2: 265-266.

${ }^{30}$ Vâiz-i Belhî, Fezâil-i Belh, 149. 
söylenmektedir. Bize göre ise bununla $\mathrm{Hz}$. Yahya b. Zekeriya kastedilmektedir. Bunun aksini savunan ve aksine inanlar kafirdir. Biz toprak üstümüze döker, kılıç boynumuza takarız ve son nefesimize kadar Allah'ın dinini savunmaya devam ederiz." 31

Diğer bir rivayete göre, Belh kapısında bir kişiye ait araziyi Halife'ye yakın olan biri kendi mülkiyetine geçirip, kendisine ait olduğuna dair de dâru'l-hilâfeden imza almıştı. Arazi sahibi Ebû Mutîyye gelip şikayette bulundu. Ebû Mutî araziyi gasp eden kişiye sordu. Adam arazinin kendisine ait olduğuna dair Halife'nin imzasını taşıyan belgeyi gösterince, Ebû Mutî' söz konusu mektubun arkasına Halife'ye hitaben şöyle yazdı: "Ben senin atadığın bir kişiyim. Allah'ın kitabı ve Peygamberin sünnetine göre hüküm verdim. Şayet sen de buna razı olursan verdiğim hükmü onayla, aksi takdirde beni görevimden azlet." Mektup daru'l-hilafeye gittiğinde birçok değerlendirmeden sonra onun verdiği hükme muvafık olarak hüküm çıkarıldı. ${ }^{32}$

\section{Selm b. Sâlim (Ö. 174/790)}

Selm b. Salim el-Belhî (ö. 174/790), fâkih ve zâhid bir zâttı. ${ }^{33}$ Ebû Mukâtil es-Semerkandî, Selm b. Sâlim'in Allah'ın yeryüzündeki rahmet pınarlarından biri olup Hz. Ömer'e benzediğini söylemektedir. Hicrî 174 yılında Mekke'de vefat etti. ${ }^{34}$ Cenaze namazını Süfyan b. Uyeyne ${ }^{35}$ kıldırdı. ${ }^{36}$

Selm, zalim hükümdarlar ve destekçilerinin yüzüne bakmanın haram olduğu konusunda hiç şüphesinin olmadığını ancak bunlarla konuşmanın helal olup olmadığını bilmediğini söylemektedir. ${ }^{37}$

Rivayete göre, Belh emiri Ali b. Îsâ "O bizi ve senin imzanı dikkate almıyor, bizim âmillerimizin şahitliğini kabul etmiyor." şeklinde mektup göndererek, Selm b. Sâlim'i Emîrü'l-mü'minîn'e şikayet ettiğinden, bazı rivayetlere göre Halife'ye hakaret ettiği ve onu eleştirdiğinden dolayı,

31 bk. Vâiz-i Belhî, Fezâil-i Belh, 146-147; Zehebî, Mîzânü'l-i'tidâl, 1: 526; Kureşî, Cevâhirü'lmudiyye, 2: 266; Temîmî, Tabakâtu's-seniyye, 3: 178-179.

32 Vâiz-i Belhî, Fezâil-i Belh, 150-151.

33 Müderris, Meșâihu Belh, 1: 84.

${ }^{34}$ Hatîb el-Bağdâdî, Târîhu Bağdâd, 10: 204; Vâiz-i Belhî, Fezâil-i Belh, 157.

35 Ebû Muhammed Süfyan b. Uyeyne b. Meymun el-Hilalî el-Kûfí, Mekke hareminin muhaddisi, sika hâfız, hadiste el-Câmi' kitabı ve bir tefsir kitabının müellifi olup, kendi döneminin büyük âlimlerindendir. Hicrî 107 senesinde Kûfe'de doğmuş ve 197 senesinde Mekke'de vefat etmiştir bk. Ebü'l-Ferec Abdurrahmân b. Ali İbnü'l-Cevzî, Sifatü's-safve, thk. Ahmed b. Ali (Kahire: Dârü'l-Hadîs, 2009), 1: 425; Hatîb el-Bağdâdî, Târîhu Bağdâd, 9: 174; Ahmed b. Abdullah Ebû Nu'aym el-İsfehânî, Hilyetü'l-evliyâ (Beyrut: Dârü'l-Fikr, 1996), 7: 270.

36 Vâiz-i Belhî, Fezâil-i Belh, 156-157.

37 Vâiz-i Belhî, Fezâil-i Belh, 157. 
Bağdat'a geldiğinde-bir rivayete göre getirildiğinde-Halife'nin adamları tarafından tutuklanıp hapse atıldı ve on sene hapiste kaldı. Hârûnürreşîd serbest bırakılması için af dilemesini bekliyordu. Af dilemeyi reddetti, Hârûn'un vefatından sonra Harun'un hanımı Zübeyde, bir rivayete göre oğlu Muhammed tarafından serbest bırakıldı. Mekke'de ve bir rivayete göre Horasan' da vefat etti. 38

\section{5. Şeddâd b. Hakîm (Ö. 214/829)}

Künyesi Ebû Osman olan Şeddâd b. Hakîm el-Belhî, ${ }^{39}$ İmam Züfer'in ashâbındandır. Altı ay Belh kadılı̆̆ını yaptıktan sonra, kadılıktan sakındı. Hicri 210, 2013 veya 214 yılında vefat etmiştir. ${ }^{40}$

Muhammed b. Sehl ${ }^{41}$ onun ilmi kişiliği hakkında şöyle demektedir:

Ben Şeddâd'tan daha âlim birini görmedim. Biz Ebû Yusuf ile bir meselede münazara ediyorduk. İki tarafın talepleri uzayıp gidince, Ebû Yusuf bana "Gel usta tabibe gidelim." dedi. Ben "O kimdir?" diye sorduğumda "Şeddâd" diye cevap verdi. Şeddâd'ın yanına varıp soruyu sorduğumuzda meseleyi öyle ince ve detaylı bir şekilde bize açıkladı ki hiçbir kapalılık ve şüphe kalmadı.

Vâiz-i Belhî Muhammed b. Seleme'den şöyle rivayet ediyor:

Şeddâd kadı iken bir adam ona gelip Belh emirinin haksızca arazisini gasp ettiğini söyledi. Şeddâd adama "Davanın doğruluğuna dair şahitlerin var mı?" diye sordu. Adam da "Evet vardır." diye cevap verdi. Şeddâd ona "Cuma namazından sonra Emir geldiğinde sen de şahitlerinle gel.” dedi. Adam gidip şahitlerini getirdi ve Şeddâd'ın gelmesini beklemeye başladı. Şeddâd bir kişinin kendisinden şikâyetçi olduğunu Emir'e iletti. Emir geldiğinde Şeddâd davacı adama "Emir'e karşı davan ne?" diye sordu. Adam da bütün özellikleri ve hudutlarını belirterek "Falan yerdeki arazilerimi emir gasp etti." dedi. Şeddâd bu kez Emir'e yönelip ondan cevap istedi. Emir, arazinin kendisine

38 bk. İbn Sa'd, et-Tabakâtü'l-kebîr, 9: 378; Hatîb el-Bağdâdî, Târîhu Bağdâd, 10: 204; Vâizi Belhî, Fezâil-i Belh, 157-158; Şemsüddîn Muhammed b. Ahmed ez-Zehebî, Siyeru a'lâmi'n-nübelâ, thk. Şu'ayb el-Arnaût v.dğr. (Beyrut: Müessesetü'r-Risâle, 1982-1988), 9: 321.

39 İbn Sa'd, et-Tabakâtü'l-kebîr, 9: 378.

40 Vâiz-i Belhî, Fezâil-i Belh, 185; Kureşî, Cevâhirü'l-mudiyye, 1: 256; Kefevî, Ketâib, 97a; Ebu'l-hasenât Muhammed Abdulhay b. Muhammed Abdilhalim el-Leknevî, el-Fevâidü'lbehiyye fi teracimi'l-Hanefiyye (Beyrut: Darü'l-Ma'rife, ts.), 83.

41 Muhammed b. Sehl b. Asker et-Temimî el-Buharî, Bağdad'a gelen hadis âlimlerinden biri ve gezici bir hâfız idi. Müslim, Tirmizî ve Nesâî’de hadislerine yer verilmiş hicrî 251 yılında vefat etmiștir bk. Hatîb el-Bağdâdî, Târîhu Bağdâd, 3: 253-254; Ali b. el-Hasen İbn Asâkir, Târîhu Medîneti Dımașk, thk. Muhibbüddîn Ebû Saî̀d Ömer b. Garâme el-Amravî (Beyrut: Dâru'l-Fikr, 1995-2000), 53: 160-165. 
ait olduğunu iddia etti. Şeddâd davacıya "Bu davayı ispat edecek şahitlerin var mı?" diye sordu. Davacı, "Evet vardır." șeklinde cevap verdi. Şeddâd şahitlerini getirmesini istedi. Adam da şahitlerini getirdi. Şahitler davalının davasını ispatlayacak şekilde şahitlik ettiler. Bunun üzerine Şeddâd, Emir'e dönerek "Söz konusu arazinin davacıya ait olduğu ispatlanmış oldu, onu sahibine teslim et!" deyince, Emir de "Teslim etmem!" dedi. Şeddâd ona "Teslim etmezsen seni hapse atarım." dedi. Bunun üzerine Emir bu sözden dolayı çok kızdı ve Şeddâd'a "Sen beni mi hapse atacaksın?" dedi. Şeddâd "Evet, seni hapse atacağım. Şayet hükmümü kabul edip araziyi teslim edersen ne âlâ, aksi takdirde 'benim hükmümü emir uygulamıyor' diye dârü'l-hilafeye mektup yazacağım ve cevap gelinceye kadar de evde oturup bekleyeceğim." şeklinde cevap verdi. Emir "Pekiyi teslim edeceğim." deyince Şeddâd ona "Sen onu sahibine teslim etmeden ben buradan dönmem." dedi. Emir, o araziden vazgeçip onu sahibine teslim etti ve ondan sonra Şeddâd geri döndü. 42

Günlerden birinde Belh valisi Şeddâd'a gelip onun yanına girmek için kendisinden izin istedi, Şeddâd ona izin verdi ve içeriye girdi. Şeddâd'ın damadı Emir'in üzerinde oturması için bir seccade sermek hedefiyle kalktığında, Şeddâd ona "Bırak serme" deyip engel oldu. Vali Şeddâd'ın yanından çıktığında "Bu şeyh aramızda olduğu müddetçe din işleri disiplin içinde olur" diyerek onun yaptığı bu davranışı takdir etti. ${ }^{43}$

\section{Leys b. Müsâvir (Ö. 224/839)}

Künyesi Ebû Yahya olan Leys b. Müsâvir/Müsafir Abdullah b. Amr b. Remmâh'tan ${ }^{44}$ sonra Belh kadılı̆̆ına atanan, Belh'in on birinci kadısıdır.

Muhammed b. Ezher İbn-i Ebî Ya'kub'dan rivayette bulunarak Belh kadılarını; Haris b. Sur (Şub?), Hilal b. Hasân, Mukatil'in babası Süleymân, Nasr Müşâris, Mütevekkil, Ömer b. Meymûn er-Remmâh, Ebû Muhammed, Ebû Mutî, Şeddâd b. Hakîm, Abdullah b. Ömer b. Meymûn er-Remmâh, Leys b. Müsâvir şeklinde sıralamış, Leys döneminde kargaşa günlerinin başladığını ve uzun bir süre mezalim dışında kadıların bulunmadığını belirtmiştir. Leys, hicrî 226 yılında, bazı rivayetlere göre ise 224 yılında vefat etti. ${ }^{45}$

Vâiz-i Belhî șöyle demektedir:

42 Vâiz-i Belhî, Fezâil-i Belh, 189-190.

43 Vâiz-i Belhî, Fezâil-i Belh, 190.

${ }^{44}$ Ebû Muhammed Abdullah b. Ömer b. Meymun er-Remmâh, Nişabur kadısıdır bk. Kureșî, Cevâhirü'l-mudiyye, 1: 279.

45 Vâiz-i Belhî, Fezâil-i Belh, 208-209. 
Rivayete göre Leys kadı iken Hilafet makamından, ${ }^{46}$ herkesin Kur'an'ın mahluk olduğunu söylemesi gerektiğini emreden bir mektup geldi. Leys bunu görünce "Allahu ekber! Seksen sene sonra müslümanların içinde küfür zâhir oldu." diyerek halkın önünde şapkasını başından çıkarıp yere vurdu ve "Kendimi kadılıktan azlettim. Kur'an'ın mahluk olduğunu iddia edenler kafirdir." ifadesini kullandı. Leys'in bu cesaretli eylemi ise bir şair tarafından şöyle övülmüştür:

$$
\begin{aligned}
& \text { واذكر أبا يميى الهزبر ليثا كان لبلخ رممة وغيثا } \\
& \text { هو الذي بَعََّ عنا الكفرا طوقنا عند الممات شكرا }
\end{aligned}
$$

Tercüme:

Belh için rahmet yağmuru olan Ebû Yahya Hizebr (güçlü aslan) Leys'i hatırla

Allah’a şükürler olsun, ölüm anında boynumuza sarılan küfrü bizden uzaklaştırdı. ${ }^{47}$

\section{Muhammed b. Sa'îd, Ebû Bekir (Ö. 328/940)}

Büyük bir fakih olan Muhammed b. Sa'id Ebû Bekir el-A'meş el-Belhî, künyesi ile meşhurdur. Ebû Bekir el-İskâf'tan ders almış, Ebû Cafer elHinduvânî'nin ise hocasıdır. ${ }^{48} 53$ yaşında iken hicrî 328 yılında vefat etmiştir. Türbesi Belh'in Buht kapısında Ebû Nasr b. Selam'ın mezarının yakınındadır. ${ }^{49}$

Bir rivayete göre halifenin âmili olan ve Sâmânî veziri Ebu't-Tayyib elMus'abî̀nin oğlu olduğu söylenen Hasan b. Ebi't-Tayyib bir bölgeden vergi istedi. Ebû Bekir bunun caiz olmadığını söyledi. ${ }^{50}$ Bunun üzerinde ikisi tartışmaya başladı. Hasan, Ebû Bekir'e: "Ey Ebû Bekir! Sultana karşı bu derecede cesaretli ve küstahça davranma!" deyince Ebû Bekir de ona "Ey Hasan! Sen de Allah'a karşı cesur ve küstah olma!” şeklinde cevap verdi. Hasan, Ebû Bekir'e "Hocan Ebü'l-Kasim es-Saffar'ın başına gelenleri unuttun mu?" deyince Ebû Bekir da ona "Peki sen hocan Ebû Tayyib el-Mus'abî̀nin başına gelenleri unuttun mu?" diye karşılık verdi. Hasan bu sözle yıkıldı, yüzü

\footnotetext{
46 Burada halifenin kim olduğu belirtilmemiştir; ancak Leys'in Şeddâd b. Hakem'den (ö. 214/829) sonra kadı olup miladi 838 veya 840 yılında vefat ettiğini göz önünde bulundurduğumuzda AbbâSî halifesi Mutasım döneminde olduğu anlaşılmaktadır.

47 Vâiz-i Belhî, Fezâil-i Belh, 10.

48 Kureșî, Cevâhirü'l-mudiyye, 1: 37, 2: 246; Kefevî, Ketâib, 119a.

${ }^{49}$ Vâiz-i Belhî, Fezâil-i Belh, 291-293.

50 Vâiz-i Belhî, Fezâil-i Belh, 293-294; Bernd Radtke, "Horasan ve Maveraünnehir'de Din Alimleri ve Mutasavvıflar”, Uluslararası Sosyal Araştırmalar Dergisi, trc. Ergin Ayan 2/9 (2009): 365.
} 
sapsarı oldu ve sustu. Nihayet Ebû Bekr'in dediğini kabul etmek zorunda kaldı. 51

\section{Yunus b. Tahir en-Nusayrî/en-Nadrî (0̈. 411/1020)}

Şeyhülislam Yunus b. Tahir en-Nusayrî/en-Nadrî̀nin künyesi Ebü’lKasim'dir. Belh'te ikamet etmiş, Belh âlimlerinin büyüklerinden olup aynı zamanda bu şehirde ilk şeyhülislam lakabı almış bir zattır. ${ }^{52}$ Birçok hadis rivayet eden Ebü'l-Kasim, İmam Ebû Hanife'nin ashâbını kapsamakta olan Behce kitabının da müellifidir. Hicrî 411 yılında vefat eden ${ }^{53}$ bu zat, Nügunbedân'ın çaprazında Penc-Reş denilen yerde defnedildi. ${ }^{54}$

Vaiz-i Belhî’nin kitabında yer alan bir rivayete göre, bir gün Sultan Mahmud ortaya çıkan bir meseleye fetva vermesi için, meseleyi yazdırıp özel adamlarının birinin aracıyla Şeyhülislam Yunus b. Tahir'e gönderdi. Şeyh, adeti üzerine sabah namazından sonra ders ile meşgul olurdu. Bu esnada fetva getirenlerin fetva kağıtlarını geliş sırasına göre üst üste koyuyorlardı. Şeyh, dersini bitirip eve gittiğinde üst üste konulmuş olan fetva kağıtlarını çeviriyor ve böylece en alttakini üstüne getirdikten sonra cevap yazmaya başlıyordu. Sultanın fetva gönderdiği günde de tesadüfen sultanın fetva kağıdı en üstte idi. Şeyh adeti üzerine fetva kağıtlarını çevirdiğinde sultanın kağıdı en sonda kalmış oldu. 0 esnada sultanın adamı geldi. Fetva kağıdının en sona kaldığını görünce şeyhe: "Önce benim getirdiğim fetvaya cevap yazmalısın." dedi. Şeyh de ona: "Senin daha sıran gelmedi." diye yanıt verdi. Şeyh, birkaç fetvaya cevap yazıncaya kadar padişahın adamı sıkıldı. Saltanattaki konumunun verdiği kibir ve böbürlenmeden dolayı beklemeye daha fazla dayanamadı. Şeyhe ısrar etmeye başladı. Şeyh ona: "Sıran gelince yazarım." dedi. 0 da şeyhe: "Benim fetvam, kağıtların en üstünde idi, şimdi ise hepsinin altında olduğunu görüyorum." dedi. Şeyh da ona "Sen herkesten sonra geldiğin için en alta gelmiştir." diye cevap verince, adam: "Bu fetva benim değil, sultanındır." dedi, Şeyh de ona: "Burada gördüğün sıra bekleyenler de benim kölelerim değil Rahman'ın kullarıdır." diye cevap

\footnotetext{
51 Vâiz-i Belhî, Fezâil-i Belh, 293-294.
}

52 bk. Ali b. Hibetillah Ebû Nasr İbn Mâkûlâ, el-İkmâl fî ref'i'l-irtiyâb 'ani'l-mü'telif ve'lmuhtelif mine'l-esmâ' ve'l-künâ ve'l-ensâb, nşr. Abdurrahman b. Yahyâ el-Muallimî elYemânî (Kahire: Dâru'l-Kitâbi'l-İslâmî, 1993), 3: 54; Abdulkerim b. Muhammed b. Mensur es-Semânî, el-Ensâb, thk. Abdurrahman b. Yahya el-Muallimî v.dğr. (Haydarâbâd: Dârü'lMeârifi'l-Osmaniyye, 1382/1962), 13: 290; İbnü'l-Esîr, el-Lübâb fî tehzîbi'l-ensâb, 1: 479; Ahmed b. Ali İbn Hacer el-Askalânî, Tabsîru'l-müntebih bi-tahrîri'l-Müsstebih, thk. Muhammed Ali en-Neccâr-Ali Muhammed el-Bicâvî (Beyrut: el-Mektebetü'l-İlmiyye, ts.),

1: 161.

53 Semânî, el-Ensâb, 5: 266; Kureșî, Cevâhirü'l-mudiyye, 2: 236.

54 Vâiz-i Belhî, Fezâil-i Belh, 319-320. 
verdi. Padişahın adamı kızdı ve şeyhe: "Fetvamı cevap yazmadan bana ver ben gideyim." dedi. Şeyh de fetva kağıdını verip ona: "Sabretseydin cevap yazardım." dedi. Adam fetva kağıdını alıp Sultan'a giderek şeyhi şikayet edip durumu anlattı. Şeyhin adâb ve adetini bilen ve onun dindarlığından ve doğruluğundan haberdâr olan Sultan, hizmetçisine: "Şeyh o fetvanın bana ait olduğunu bildi mi? diye sordu. Hizmetçi de Sultan'a: "Evet, ayrıca ben ona ısrarla söyledim ama o yine de yazmadı." dedi. Sultan: "Git, evinde sergi, kap, vs. mallardan ne varsa hepsini yağmala, hepsini sana bağışladım." dedi. Sultan; Şeyh'in takvasını, dindarlı̆̆ını, dünyayı terk ettiğini, emanete riayet etme konusundaki hassasiyetini ve Allah'tan başkasından müstağni olduğunu biliyor ama hizmetçiye ders vermek istiyordu. Hizmetçi gidip hemen geri döndü ve Sultan'a:

Ey cihanın sultanı! Ben onun evinden neyi alacağım, neyi yağmalayacağım ki! Evinde bir hasır vardır o da yırtık, kumaşlardan, kaplardan ve elbiselerden ise bir kırık kap, bir kırık divit ve bir kırık sürahi dışında başka bir şey yoktur.

Bunun üzerine sultan ona:

Ey nâkıs! Âlim ve şeyh bu sıfatla mevsuf olursa, kamil bir ilim sahibi olduğu halde dünya malından bahsettiğin şeylerle kanaat ediyorsa, benim sakalım, senin bıyığın, benimle senin övme ve yermemiz, senin huysuzluğun ve nazın umurunda mı ki? Bekle sıran geldiğinde cevap yazsın getir." dedi. ${ }^{55}$

\section{Sonuç}

İslam tarihinde zaman zaman siyaset, fikıh ve hukuka yön vermiştir. Buna bağlı olarak da bazen insanlar haksızlığa maruz kalmış ve bazen de iktidar, mezheplerin yayılışına bile müdahale edebilmiştir. Ama bu duruma, nadiren vuku bulunan bir vakıa diyebiliriz. Bu istisnai durumun karşısında genel olarak İslam âlimlerinin, özel olarak da fıkıh âlimlerinin özgür düşünceleriyle yaptıkları ictihâdlarda, verdikleri fetvalarda hiç kimsenin baskısı altında kalmayı kabul etmediklerini ve hiç kimseden çekinmeden doğru olarak bildiklerini haykırdıklarını görmekteyiz.

Fıkıh ve fukahâ ile meşhur olmuş Belh şehrinin fukahâsına baktığımız zaman yöneticilere karşı sergiledikleri dik duruşlarıyla da örnek olduklarını öğrenmekteyiz. Zaman zaman zor durumlarla karşılaştıklarına hatta canlarına mal olmasına rağmen en basit meselelerde bile taviz vermeyip dik durmaya devam ettiklerini müşahede etmekteyiz. Adaletsizliğin temelinde yer alan ve $\mathrm{Hz}$. Peygamber'in ifadesiyle eski ümmetlerin helak olmasına

55 Vâiz-i Belhî, Fezâil-i Belh, 320-323. 
sebep olan hukukun uygulamasında güçlü ile güçsüz arasında ayrım yapma konusunda çok hassas davranarak, padişah ile diğer sıradan vatandaşlara karşı aynı muamelede bulunduklarını da görmekteyiz. Örnek olarak verdiğimiz bu duruşlar, müçtehitlerin dürüstlügünü ve ictihâdlarının sağlamlığını göstermesi açısından önem arz etmektedir.

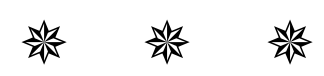

\section{KAYNAKÇA}

ASKALÂNÎ, Ahmed b. Ali İbn Hacer. Tabsîru'l-müntebih bi-tahrîri'l-Müștebih. Thk. Muhammed Ali en-Neccâr-Ali Muhammed el-Bicâvî. 4 Cilt. Beyrut: el-Mektebetü'l-İlmiyye, ts.

ASKALÂNİ, Ebü'l-Fadl Şihabuddîn Ahmed b. Ali İbn Hacer. Tehzibu't-tehzîb. 14 Cilt. Beyrut: Dârü'l-Fikr, 1404/1984.

BROCKELMANN, Carl. Tarihu'l-edebi'l-Arabî. Trc. Abdulhalim en-Neccâr. 5. Bs, 6 Cilt. Mısır: Dârü'l-Meârif, ts.

FURKANI, Mehterhan. "Afganistan Topraklarında Yetişmiş Hanefi Fıkıh Alimleri”. İslam Hukuku Araştırmaları Dergisi. 28 (2016): 327-350.

HALíLÎ, Halil b. Abdullah b. İbrahim b. Halil Ebu Ya'la. el-İrşad fi ma'rifeti ulemâi'l-hadis. Thk. Muhammed İdris Ömer İdris. 3 Cilt. Riyad: Mektebetu'r-Rüşd, 1409/1989.

HAMEVÎ, Ya'kut b. Abdillah. Mu'cemü'l-büldân. 2. Bs, 7 Cilt. Beyrut: Dârü Sâdir, 1995.

HATîB EL-BAĞDÂDÎ, Muhammed b. Ali. Târîhu Bağdâd. Thk. Beşşâr 'Avvâd Ma'rûf. 17 Cilt. Beyrut: Dârü'l-Garbi'l-İslâmî, 2001.

İBN ASÂKİR, Ali b. el-Hasen. Târîhu Medîneti Dımaşk. Thk. Muhibbüddîn Ebû Sa'îd Ömer b. Garâme el-Amravî. 80 Cilt. Beyrut: Dâru'l-Fikr, 19952000.

İBN KUTLUBOĞA, Ebu'l-Feda Zeynuddîn Kasım b. Kutluboğa es-Sudûnî. Tâcü't-terâcim fì tabakâti'l-Hanefîyye. Dımaşk: Dârü'l-Kalem, 1413/1992.

İBN MÂKÛLÂ, Ali b. Hibetillah Ebû Nasr. el-íkmâl fî ref'i'l-irtiyâb 'ani'l-mü'telif ve'l-muhtelif mine'l-esmâ' ve'l-künâ ve'l-ensâb. Nşr. Abdurrahman b. Yahyâ el-Muallimî el-Yemânî. 7 Cilt. Kahire: Dâru'l-Kitâbi'l-İslâmî, 1993.

İBN SA'D, Muhammed b. Sa'd b. Menî‘. et-Tabakâtü'l-kebîr. Thk. Ali Muhammed Ömer. 11 Cilt. Kahire: Mektebetül-Hancî, 2001.

İBNÜ'L-CEVZÎ, Ebü'l-Ferec Abdurrahmân b. Ali. Slfatü's-safve. Thk. Ahmed b. 
Ali. 2 Cilt. Kahire: Dârü'l-Hadîs, 2009.

İBNÜ'L-ESÎR, İzzüddîn Alî b. Muhammed el-Cezerî. el-Lübâb fî tehzîbi'l-ensâb. 3 Cilt. Bağdâd: Mektebetü'l-Müsennâ, ts.

İMÂDÎ, Muhammed Hasan Abdülkerim. Horâsân fî asri'l-Gaznevî. b.y.: Müessesetü Hammâde li'l-Hademât ve'd-Dirasâti'l-Camiîyye ve Dârü'lKindî li'n-Neşri ve't-Tevdî', ts.

İSFEHÂNî, Ahmed b. Abdullah Ebû Nu'aym. Hilyetü'l-evliyâ. 10 Cilt. Beyrut: Dârü'l-Fikr, 1996.

İSTAHRî, Ebu İshak İbrahim b. Muhammed el-Farisî. el-Mesâlik ve'l-memâlik. Beyrut: Dârü Sâdir, 2004.

KEFEVÎ, Mahmud b. Süleyman. Ketâibü a'lâmi'l-ahyâr min fukahâ'i mezhebi'nNu'mâni'l-muhtâr. 1041: 81a-119a. Rağib Paşa Kütüphanesi.

KUREŞî, Ebû Muhammed Abdülkâdir b. Muhammed. el-Cevâhirü'l-mudiyye fî tabakâti'l-Hanefiyye. 2 Cilt. Dekken: Matba'atü Meclis-i Dâireti'lMe'ârifi'n-Nizâmiyye, 1914.

KUREŞî, Îman bt. Suûd b. Hayşân. el-Hayâtü'l-ilmiyye fi Belh hılâle'l-fetra 205617/820-1220. Yüksek Lisans Tezi, Camiatü Ümmi'l-Kurâ, 1434/2013.

LEKNEVÎ, Ebu'l-hasenât Muhammed Abdulhay b. Muhammed Abdilhalim. elFevâidü'l-behiyye fî teracimi'l-Hanefiyye. Beyrut: Darü'l-Ma'rife, ts.

MAKDİSî, Ebû Abdillah Muhammed b. Ahmed. Ehsenü't-tekâsîm fî ma'rifeti'lekâlîm. Kahire: Mektebetü Medbûlî, 1411/1991.

MEKKÎ, Muvaffak b. Ahmed b. Muhammed Kerderî, Muhammed b. Muhammed b. Şihâb el-Bezzâzî. Menâkibü'l-Imami'l-A'zam Ebî Hanîfe. Haydarâbâd: Matbaatü Dâireti'l-Mearifi'n-Nizamiyye, 1321/1903.

Mi̇Zî, Yûsuf b. ez-Zekî Abdurrahmân Ebü'l-Haccâc. Tehzîbü'l-Kemâl. Thk. Beşşâr Avvâd Ma'rûf. 35 Cilt. Beyrut: Müessesetü'r-Risâle, 1983-1992.

MÜDERRIS, Muhammed Mahrûs Abdullatif. Meşâihu Belh mine'l-Hanefiyye ve mâ inferedû bihî mine'l-mesâili'l-fikhiyye. Bağdad: Darü'l-Arabiyye, 1979.

RADTKE, Bernd. "Horasan ve Maveraünnehir'de Din Alimleri ve Mutasavviflar". Uluslararası Sosyal Araştırmalar Dergisi. Trc. Ergin Ayan 2/9 (2009): 358-376.

SEMÂNî, Abdulkerim b. Muhammed b. Mensur. el-Ensâb. Thk. Abdurrahman b. Yahya el-Muallimî v.dğr. Haydarâbâd: Dârü'l-Meârifi'l-Osmaniyye, 1382/1962.

ŞENER, Mehmet. "Ebu Mutî̀ el-Belhî". Türkiye Diyanet Vakfi İslâm 
Mehterhan FURKANI

Ansiklopedisi. 10: 194-195. İstanbul: TDV Yayınları, 1994.

TEMÎMÎ, Takiyyuddîn b. Abdulkâdir el-Gazzî el-Mısrî. et-Tabakâtu's-seniyye fî terâcimi'l-Hanefîyye. Thk. Abdulfettah Muhammed el-Hulv. 4 Cilt. Kahire: Dârü'l-Kütüb, 1390/1970.

VÂiZ-İ BELHÎ, Ebu Bekir Abdullah b. Ömer b. Muhammed b. Dâvûd. Fezâil-i Belh. Thk. Abduhay HabibîTrc. Abdullah Muhammed b. Hüseyin Hüseynî el-Belhî. Tahran: Cengelek, 1388/2009.

ZEHEBÎ, Ebû Abdillah Muhammed b. Ahmed. Mîzânü'l-i'tidâl fî nakdi'r-ricâl. Thk. Muhammed Rıdvân Arkasûsî v.dğr. 5 Cilt. Beyrut: Dâru'rRisâleti'l-Âlemiyye, 2009.

ZEHEBÎ, Şemsüddîn Muhammed b. Ahmed. Siyeru alâmi'n-nübelâ. Thk. Şu'ayb el-Arnaût v.dğr. 25 Cilt. Beyrut: Müessesetü'r-Risâle, 19821988.

ZİRİKLÎ, Hayreddîn b. Mahmûd. el-A'lâm. 8 Cilt. Beyrut: Dâru'l-İlm li'l-Melâîn, 2002.

泾泾 


\title{
THE STANCES OF BALKH JURISPRUDENCES AGAINST THE RULERS: IN THE CONTEXT OF FADAEL-E BALKH
}

\author{
(1) Mehterhan FURKANİ
}

\section{Extended Abstract}

The imams of the four Sunni fiqh sects are the first examples for us in order not to give up one's own principles because of the pressure and threats of the rulers. Abu Hanifah had been imprisoned and finally killed, Malik bin Anas had been tortured and lost his arm, Mohammad bin Edris al-Shafiî had faced various threats, exiled from one place toanother, Ahmad bin Hanbal also faced various problems; however, they were all upright until the end and made no concessions. When we look at the jurisprudences of the city of Balkh, we can see that, they had continued to exhibit the same behavior, they had worked in the administration with just rulers as Qadis and muftis however, we also see that they had taken a distance from the administration when necessary and that they never bowed to the pressures and threats of the rulers regarding the right, truth and defending the right. In this article, we will examine a few examples of the behavior of scholars who were born, lived or attributed to the city of Balkh until the beginning of the 7th century hijri, against the rulers, based on the work titled Fadael-e Balkh. We think that the subject is important in terms of being an example of the fact that fiqh scholars had not been under the influence of anyone while producing judicial duties, although there are some exceptions.

We will give some example from the scholars of the city of Balkh, because this city is an important center of the fiqh and Hanafi sect. It has also been the capital city of many governments. Abu Dawoud Amir of Balkh, despite fighting against him, because of his courage and honesty, wanted to appoint Mutawakkil b. Humran al-Qadi (d. 141 / 758-9) as Qadî of Balkh city, but Mutawakkil accepted the mentioned duty on conditions that the name of the

a Asst. Prof., Aksaray University, mehterhan_4@windowslive.com 
governor is not read in the pulpit, the witnesses of the people he appointed will not be heard, and that the governor and the army return the goods they received from the Muslims to their owners. One day the caliph writes to him that: "Do not judge on matters specific to us!" Mutawakkil writes on the back page of his letter the verse of Qur'an "God commands you to return that which had been entrusted to you to their rightful owners..." [Al-Nisa, 4/58] and sent the letter back to him. Then two people brought him a case. Since one of them was the relative of the governor, Mutawakkil didn't accept his testimony and ordered him to be removed from the village for the time being. When this news reached the governor, he imprisoned Mutevekkil for 40 days and later on ordered to him to recite his name in the minbar (pulpit) and accept his testimony. When Mutawakkil refused, the governor cut his hands, feet and head. A person who was one of the relatives of the Caliph extorted another's land and got a signature paper from the caliph proving that the land belongs to him. The owner of the land goes to Abu Mutî Hakam (d.199/814), who was one of the students of Abu Hanifah and was Balkh's Qadi for 16 years, and made a complaint. When Abu Mutî requested evidence from the usurper, he showed him the document bearing the signature of the Caliph. Abu Muti wrote to the Caliph on the back of the letter that: "I am a person you appointed. I decided on this matter according to the book of Allah and the sunnah of the Prophet. Either you agree with this decision or release me of my duty." When the letter reached the caliph, after a long consultation, the caliph confirmed his judgment. Ali b. Isa, Governor of Balkh complained about Salm b. Salim al-Balkhi (d. 174/790) by sending a letter to caliph Harun al-Rashid, saying "He does not consider our and your signature, he does not accept the testimony of our officers." When he arrived in Baghdad, he was arrested and imprisoned by the Caliph's men. Harun al-Rashid waited for him to beg for forgiveness to be released; however, he refused to ask forgiveness and remained in prison for ten years, he was only able to leave the prison after Caliph's death. When Shaddâd b. al-Hakam al-Balkhi (d. 214/829) was the qadi of Balkh a man came to him and told him that the governor of Belh has unfairly seized his land. Shaddâd requested the land owner to bring witnesses. When it is proved that the land belonged to the plaintiff, he asked Emir to deliver the land to its rightful owner. When governor said that" I will not " Shaddad said to him, "If you do not, I will put you in jail. Shaddad said "You will put me in jail?" Qadi answered "Yes, if you accept my verdict and deliver the land to its owner there won't be a problem, otherwise I will write a letter to Caliph saying "The governor does not apply my verdict" and I will sit and wait here until the answer comes." Then he waited until governor 
delivered the land to its owner. Mohammad b. Said Abu Bakr al-Balkhi (d. 328/940), opposed to a tax demand of Hasan b. Abi Tayyib who was said to be the son of Vazeer of Samanî Abu al- Tayyib al- Mus'abî who was also the operative of the Caliph, from a region. Hasan said to Mohammad Sa'id: " Do not be so brave and arrogant towards the sultan!" Mohammad answered: "You do not be so brave and arrogant towards God!" Hasan said to him: "Did you forget what happened to your teacher Abu Bakr al-Saffar?" He answered: "Did you forget what happened to your teacher Abu al-Tayyib Al-Mus'abi?" Finally, he had to accept what Abu Bakr said. Sultan Mahmud b. Sabuktigin, wrote down an issue and sent it to Yunus b. Tahir (d. 411/1020) who was the first Sheikh al-Islam of Balkh, to ask for fatwa. When the envoy of the Sultan came, the sheik asked him to wait for his turn. "This fatwa is the Sultan's, not mine, you have to answer it first," said the envoy. The Sheikh replied to him: "Those who wait for their turn you see here are not my slaves, but the servants of Rahman." The sultan's man got angry and said: "Give me my letter without answering. I will go." The Sheikh gave the fatwa paper and said: "If you were patient, I would answer." Sultan's envoy took the fatwa paper and went back to the Sultan. He complained about the sheikh and explained the situation. The Sultan said to him: "Go again and wait for your turn.

Keywords: Islamic Law, Jurisprudences, Balkh, Rulers, Stances of Scholars Against to Rulers.

$$
\text { 淡谈 }
$$

